\title{
THE DORSAL SKINFOLD CHAMBER: A VERSATILE TOOL FOR PRECLINICAL RESEARCH IN TISSUE ENGINEERING AND REGENERATIVE MEDICINE
}

\author{
M.W. Laschke* and M.D. Menger \\ Institute for Clinical \& Experimental Surgery, Saarland University, 66421 Homburg/Saar, Germany
}

\begin{abstract}
The dorsal skinfold chamber is a rodent model for noninvasive microcirculatory analyses of striated muscle and skin tissue throughout an observation period of 2-3 weeks. In combination with intravital fluorescence microscopy, this model allows the quantitative assessment of dynamic processes such as inflammation, angiogenesis, vascular remodelling and microcirculation. Accordingly, the dorsal skinfold chamber is increasingly used for preclinical research in tissue engineering and regenerative medicine. This includes studies on biocompatibility, vascularisation and incorporation of medical implants and artificial tissue constructs. Moreover, the chamber implantation procedure has been modified to analyse primary and secondary wound healing as well as revascularisation and blood perfusion of dermal substitutes, skin grafts and myocutaneous flaps. Hence, the dorsal skinfold chamber model does not only provide deep insights into fundamental regenerative mechanisms but also represents a versatile tool for the development of novel therapeutic strategies.
\end{abstract}

Keywords: Tissue engineering, angiogenesis, inflammation, microcirculation, biocompatibility, scaffold, skin, dermal substitute, wound healing, flap.

*Address for correspondence:

Matthias W. Laschke, M.D., Ph.D.

Institute for Clinical \& Experimental Surgery

Saarland University

D-66421 Homburg/Saar, Germany

Telephone number: +4968411626554

Fax number: +496841 1626553

Email: matthias.laschke@uks.eu

\section{Introduction}

Regenerative medicine is a rapidly growing research field, including complex in vivo processes such as the wound healing cascade (Reinke and Sorg, 2012), acute and chronic tissue responses to medical implants (Anderson et al., 2008 ) and the vascularisation and integration of skin grafts and surgical flaps (Hallock and Morris, 2011). All of these processes are characterised by a highly dynamic interaction of signalling molecules, cells and the microcirculation. Hence, they cannot be simulated in vitro or in silico. Accordingly, there is a strong need for sophisticated animal models, which allow standardised analyses under in vivo conditions. This is a major prerequisite for the successful transfer of novel regenerative approaches into clinical practice.

The dorsal skinfold chamber is such a model. It has been broadly used to investigate microcirculation physiology (Funk et al., 1983; Gerstberger et al., 1988), microcirculatory effects of anaesthesia (Franke et al., 1982; Franke and Endrich, 1983), bacteria-endothelial cell interaction (Pappelbaum et al., 2013), inflammation and sepsis (Hoffmann et al., 2004; Hillgruber et al., 2014; de Miranda et al., 2015), haemorrhagic shock (Ortiz et al., 2014), thrombosis and thrombolysis (Boulaftali et al., 2012; Ampofo et al., 2015a), ischaemia and reperfusion (Menger et al., 2003; Ampofo et al., 2016), tissue and organ transplantation (Funk et al., 1986; Bordel et al., 2006; Wittig et al., 2013), endometriosis (Laschke and Menger, 2007; Nenicu et al., 2014), hereditary haemorrhagic telangiectasia (Garrido-Martin et al., 2014) as well as tumour biology and therapy (Debergh et al., 2010; Baron et $a l ., 2011)$. The model is based on the chronic implantation of an observation chamber (Fig. 1) on the dorsal skinfold of rats, hamsters or mice. This provides continuous access to striated muscle, i.e. panniculus carnosus, subcutis and cutis for repetitive, non-invasive intravital microscopic analyses throughout an observation period of 2-3 weeks (Menger et al., 2002).

During the last two decades, an increasing number of studies indicates that the dorsal skinfold chamber is a versatile tool for preclinical research in tissue engineering and regenerative medicine. This model is frequently used for the evaluation of medical implants and engineered tissue constructs, because they can be easily implanted into the chamber and because their biocompatibility and vascularisation can be repetitively studied by means of intravital fluorescence microscopy. In addition, the chamber implantation and tissue preparation procedure have been modified in different ways to set ideal conditions for the in vivo analysis of primary and secondary wound healing as well as revascularisation and blood perfusion of 


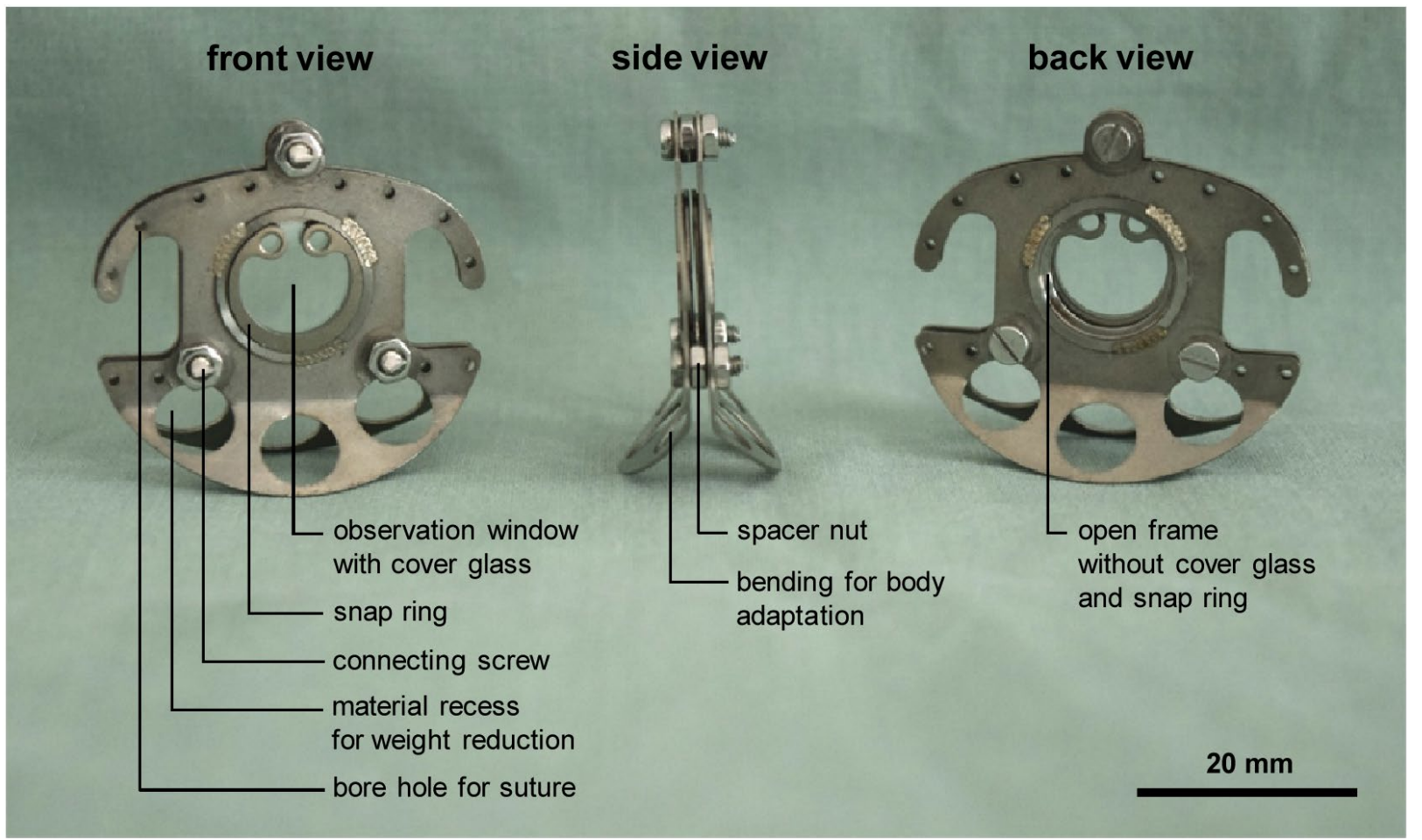

Fig. 1. Mounted dorsal skinfold chamber for mice.

skin grafts, dermal substitutes and myocutaneous flaps. In this review, we provide an overview of these approaches and novel insights into fundamental regenerative processes, which have been achieved by these approaches.

\section{Medical implants and engineered tissue constructs}

The preparation of the dorsal skinfold chamber has been described previously in detail (Laschke et al., 2011). It involves the implantation of two symmetrical titanium or polymer frames onto the back of the anaesthetised animal. During the implantation of the frames, one layer of cutis, subcutis and panniculus carnosus muscle is carefully removed in a circular area at the front side of the chamber, which serves as the observation window for subsequent analyses. Hence, this window finally includes the contralateral layer of panniculus carnosus muscle, subcutis and skin (Fig. 2a). The exposed tissue is attached to a cover glass, which is fixed with a snap ring in the chamber frame.

The dorsal skinfold chamber bears the major advantage that it can be horizontally positioned under a microscope for repetitive, non-invasive intravital microscopy in transillumination or fluorescence epi-illumination technique. After the application of different fluorescent dyes, the epi-illumination approach allows high-resolution imaging and computer-assisted quantitative analyses of distinct microvascular, cellular and molecular mechanisms. Typical examples are the visualisation of individual microvessels by intravenous injection of the plasma marker fluorescein isothiocyanate (FITC)-labelled dextran for the assessment of microhaemodynamic parameters and angiogenic processes (Ring et al., 2011a; Feng et al., 2014) or the in situ staining of leukocytes with rhodamine $6 \mathrm{G}$ to study their interaction with the microvascular endothelium during inflammation (Ampofo et al., 2015b). Apoptotic cells can be identified by an increased nuclear chromatin condensation and fragmentation by topical bisbenzimide staining (Vollmar et al., 2001).

The dorsal skinfold chamber model is frequently used for implant research, because the cover glass of the observation window can be temporarily removed for the implantation of biomaterials and engineered tissue constructs onto the panniculus carnosus muscle (Laschke et al., 2011). For this purpose, the animals are allowed to recover from the surgical trauma of the chamber preparation procedure for $48-72 \mathrm{~h}$ prior to implantation to guarantee physiological conditions for the analysis of the inflammatory and angiogenic host tissue response to the implants. The size of the implants is restricted to $\sim 3 \times 3 \times 1 \mathrm{~mm}$ for an air-free closure of the chamber and to enable analyses of the implants themselves and the surrounding tissue. Accordingly, the implants cannot be tested in a size, which is normally needed for clinical applications. Moreover, the host tissue inside the chamber is not always identical to the host tissue at the orthotopic implantation site of certain biomaterials. Hence, this different environment may not allow the direct comparison of the obtained results with findings from orthotopic studies. On the other hand, the experimental setting of the dorsal skinfold chamber allows the in vivo evaluation of many different types of implants under highly standardised conditions.

The use of biomaterials in regenerative medicine always raises the question of biocompatibility and vascularisation. A good biocompatibility is an essential prerequisite for a safe long-term implantation and function 

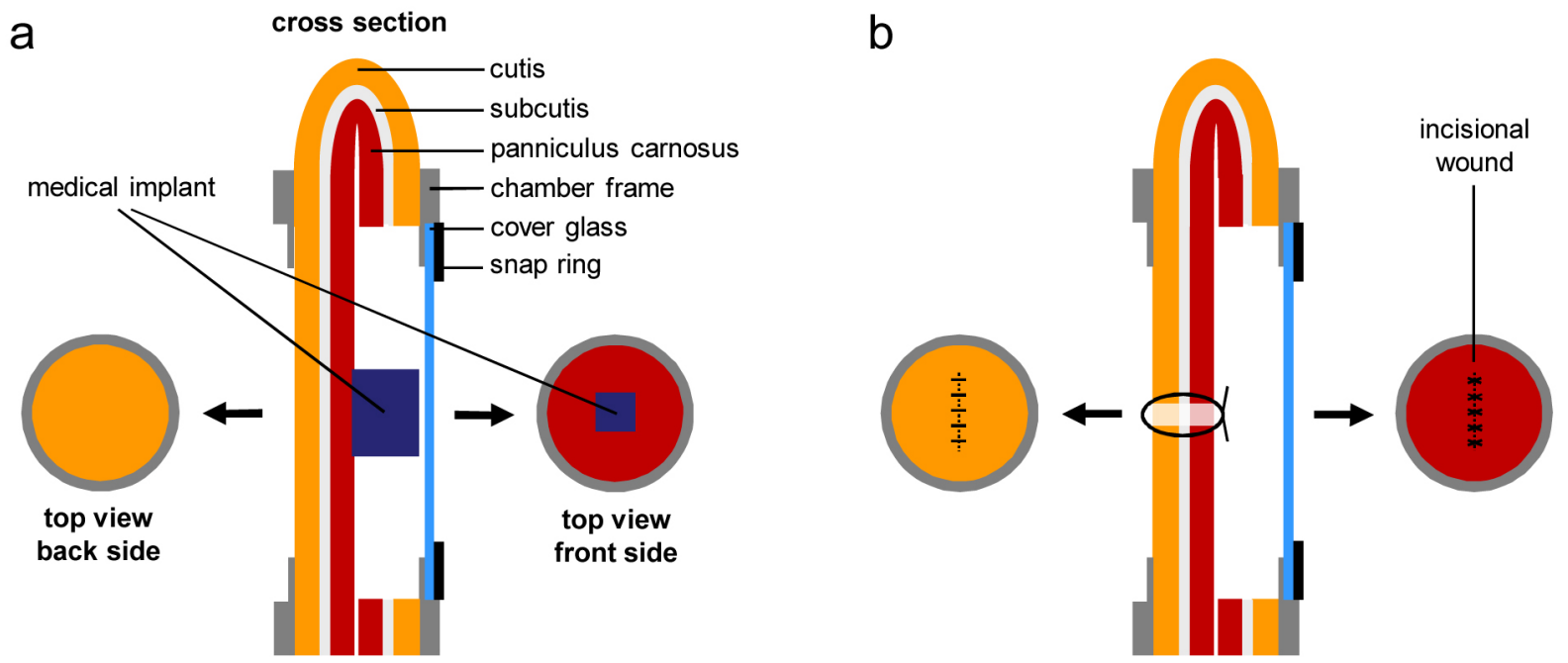

C

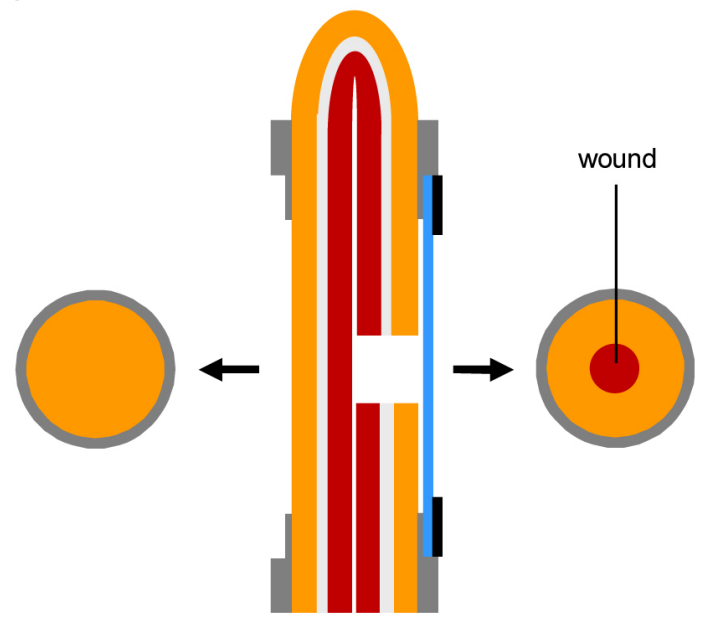

d

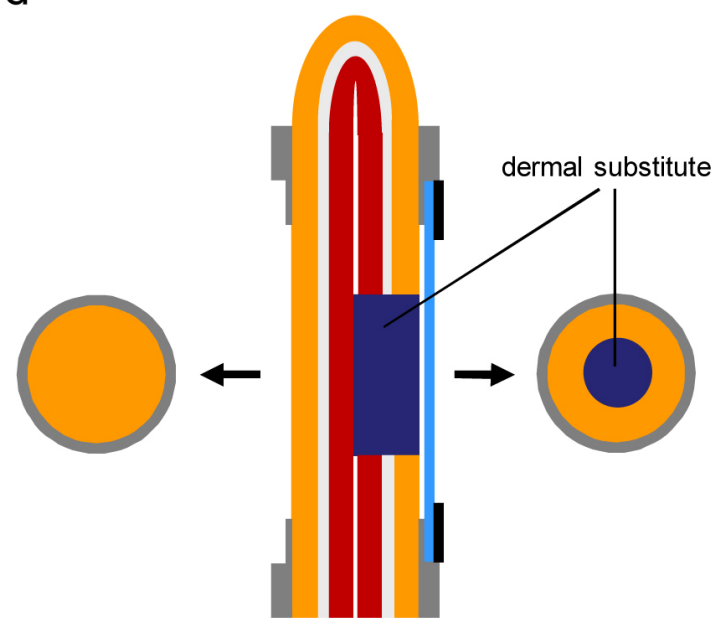

$f$

e
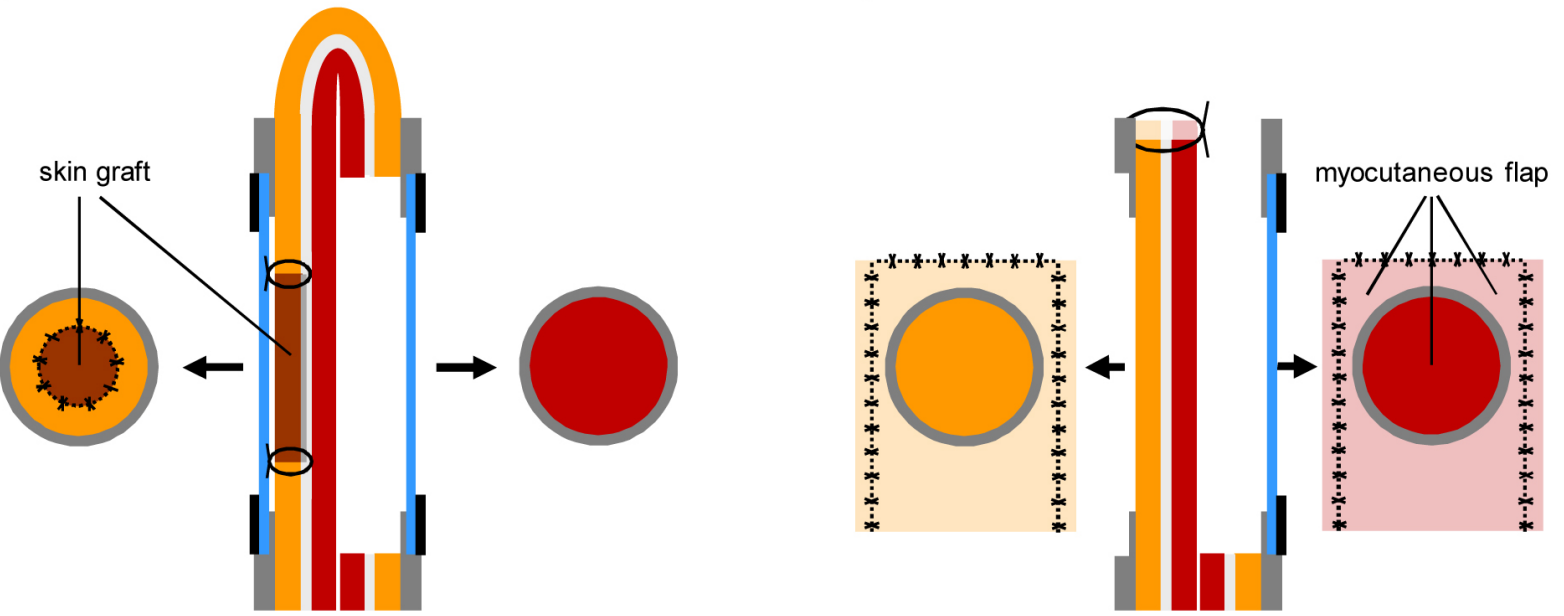

Fig. 2. Different applications of the dorsal skinfold chamber model for analyses in the field of tissue engineering and regenerative medicine, as described in the corresponding sections of this review article. The schematic crosssections display a dorsal skinfold chamber for the analysis of medical implants and engineered tissue constructs (a), healing of primary (b) and secondary wounds (c), dermal substitutes (d), skin grafts (e) and myocutaneous flaps (f). 
of biomaterials without inducing severe local or systemic inflammatory side effects (Shard and Tomlins, 2006). A rapid and sufficient vascularisation is important for the adequate incorporation of medical implants into the surrounding host tissue and the survival of cells within tissue constructs (Rouwkema and Khademhosseini, 2016). By means of the dorsal skinfold chamber model it has been shown that the two factors are crucially dependent on each other. Biomaterials which do not induce any inflammatory host tissue response also exhibit a poor vascularisation after implantation (Laschke et al., 2010). In fact, vascular ingrowth into implanted biomaterials is only promoted in the presence of a temporary moderate tissue inflammation (Rücker et al., 2006; Rücker et al., 2008; Laschke et al., 2014). In contrast, a prolonged severe inflammation inhibits angiogenesis at the implantation site (Rücker et al., 2006). This indicates that controllable pro-inflammatory conditions are beneficial for the incorporation process.

The biological reaction to biomaterials is crucially determined by the physico-chemical characteristics of their surface, their porosity and degradation kinetics. Surface activation by gas plasma treatment improves vascular ingrowth into polymer-based and allogenic bone implants in mouse dorsal skinfold chambers (Ring et al., 2007; Ring et al., 2011b). However, dependent on the used raw material this type of treatment may also generate nanorough surfaces which, for instance, impair cell attachment and vascularisation of porous polyethylene $\left(\right.$ Medpor $\left.^{\circledR}\right)$ (Laschke et al., 2016). Druecke et al. (2004) found that poly(ether ester) block-copolymer implants with large pores of 250-300 $\mu \mathrm{m}$ exhibit more blood vessels after implantation when compared to implants with smaller pore sizes. In line with these findings, Abshagen et al. (2009) further detected a stronger angiogenic response to the synthetic bone grafting substitute NanoBone ${ }^{\circledR}$ when implanted as widely spaced small granules in comparison to large solid plates. Biodegradation of biomaterials has been shown to induce angiogenesis at the implantation site (Ghanaati et al., 2009). Of interest, degraded areas within implants may even enable a guided neovascularisation (Laschke et al., 2007).

Beside the characterisation of different biological responses to distinct biomaterial properties, the dorsal skinfold chamber model has been used to assess the efficiency of novel vascularisation strategies for tissue engineering. A common approach is the coating of scaffold biomaterials with different pro-angiogenic factors, including vascular endothelial growth factor (VEGF) (Lindhorst et al., 2010; Strieth et al., 2010), sphingosine 1-phosphate (Sefcik et al., 2008), human host defence peptide LL37 (Steinstraesser et al., 2006), phthalimide neovascular factor (PNF)-1 (Wieghaus et al., 2008) and stromal derived factor (SDF)-1 $\alpha$ (Krieger et al., 2016). Moreover, scaffolds are vitalised with growth factor-secreting cells, such as mesenchymal stem cells (MSCs) (Kampmann et al., 2013; Schumann et al., 2014), osteoblasts (Schumann et al., 2009; Tavassol et al., 2010) or chondrocytes (Ehrmantraut et al., 2012), to induce angiogenesis at the implantation site. However, because the physiological growth rate of microvessels is not faster than $\sim 5 \mu \mathrm{m} / \mathrm{h}$ (Utzinger et al., 2015), the angiogenic ingrowth of host blood vessels into large three-dimensional tissue constructs is not sufficient to guarantee the survival of seeded cells. Accordingly, there is a clear trend towards prevascularisation strategies (Laschke and Menger, 2016). These strategies focus on the generation of intrinsic microvascular networks within tissue constructs, which are rapidly blood perfused by forming interconnections with the surrounding host microvasculature after implantation. This can be achieved by seeding scaffolds with adipose-derived MSC spheroids, which promote more effectively the simultaneous development of microvascular networks at different locations inside the implants when compared to seeded single MSCs (Laschke et al., 2013). Another promising approach is the seeding of scaffolds with microvascular fragments, which are enzymatically isolated in large amounts from fat tissue and consist of fully functional arteriolar, capillary and venular vessel segments (Laschke and Menger, 2015). After implantation, the microvascular fragments reassemble to blood-perfused microvascular networks and, thus, markedly contribute to the rapid vascularisation of implanted tissue constructs (Laschke et al., 2012).

\section{Primary wound healing}

For the analysis of primary wound healing, the dorsal skinfold chamber is prepared as described above, containing one layer of panniculus carnosus muscle, subcutis and skin (Fig. 2a). Subsequently, these layers are carefully cut with a scalpel over a length of $7 \mathrm{~mm}$ in the centre of the observation window and the edges of the resulting incisional wound are sutured with $9 / 0$ Nylon at $1 \mathrm{~mm}$ intervals (Figs. 2b and 3a). The tissue preparation is kept moist with physiological saline and sealed with a cover glass, which provides continuous access to the healing wound throughout an observation period of 2-3 weeks. This time period is sufficient to study the entire incisional wound healing process, including the early inflammatory phase as well as the formation of a vascularised granulation tissue surrounding the sutures. Importantly, intravital fluorescence microscopy enables the visualisation of individual vascular sprouts and newly formed microvessels within the wound margins. Thus, this approach does not only provide detailed insights into microvascular network morphology and remodelling but also into microhaemodynamic changes during incisional wound healing.

Contaldo et al. (2012) prepared incisional wounds in dorsal skinfold chambers of mice genetically depleted of apolipoprotein $\mathrm{E}\left(\mathrm{ApoE}^{-/}\right)$, which were repetitively treated with radial pressure waves. They found that this type of treatment significantly improved primary wound healing in the hypercholesterolaemic mice by promoting functional angiogenesis and enhancing tissue organisation. They also observed an increased expression of caspase-3, proliferating cell nuclear antigen and endothelial nitric oxide synthase (eNOS) in the early phase of the healing process, indicating that the treatment with radial pressure waves may facilitate the linear progression of the wound healing cascade. In the identical experimental setting, 
Elsherbiny et al. (2012) demonstrated that repetitive application of erythropoietin (EPO) reverses microvascular dysfunction in hypercholesterolaemic mice (Figs. 3b-g). EPO treatment stimulated angiogenesis and increased the capacity of wound endothelial cells to produce nitric oxide (NO) through enhanced EPO receptor and eNOS expression. This resulted in an improved blood perfusion of the wound margins comparable to that in normal healing wild-type animals. Accordingly, systemic EPO therapy may represent a promising strategy to restore the angiogenic tissue response of patients with microangiopathy during wound healing.

\section{Secondary wound healing}

In the secondary wound healing model, the two chamber frames are first completely fixed to the dorsal skinfold of the animals without tissue preparation. Subsequently, a round shaped full-thickness dermal wound with a defined diameter of 3-4 $\mathrm{mm}$ is created in the centre of the observation window by removing one layer of cutis, subcutis and panniculus carnosus muscle using a biopsy punch and microsurgical instruments (Fig. 2c). The wound is rinsed with physiological saline and the observation window is closed with a cover glass to study wound healing under wet conditions. However, it is also possible to omit the cover glass for the analysis of dry wounds as in other well established wound healing models such as the ear of the hairless mouse (Kuehnl et al., 2013; Yousefi et al., 2014). In both cases, it is mandatory to depilate thoroughly the skin of the animals during the preparation procedure to guarantee ideal imaging conditions without interfering growing fur in the observation window. Alternatively, hairless mice may be used. Ideally, they should exhibit an intact immune system, such as SKH1 mice (Benavides et al., 2009), to exclude severe effects of immunosuppression, as known for nude mice, on inflammation and angiogenesis during wound healing.

The closure of wounds in loose-skinned rodents is typically associated with wound contraction by the panniculus carnosus muscle and myofibroblasts (Horan et al., 2005; Davidson et al., 2013). The prevention of this contraction is one of the major prerequisites for the establishment of reliable models adequately reflecting secondary wound healing by granulation tissue formation in humans. In the dorsal skinfold chamber model this is achieved by spanning the double layer of skin between the chamber frames. After positioning the observation window under a stereomicroscope, continuous wound closure can be quantitatively analysed by planimetric measurements of epithelialised wound areas (Figs. 4a-f). Intravital fluorescence microscopy further provides detailed insights into microvascular changes during the wound healing process. Sorg et al. (2007) found that the skin in the observation window of the chamber exhibits an outer radial pattern of vessels which supply an inner circular ring of newly formed vessels at the wound margin. In the course of inwards directed epithelialisation, the inner circular ring progressively grows as a moving vascularisation front
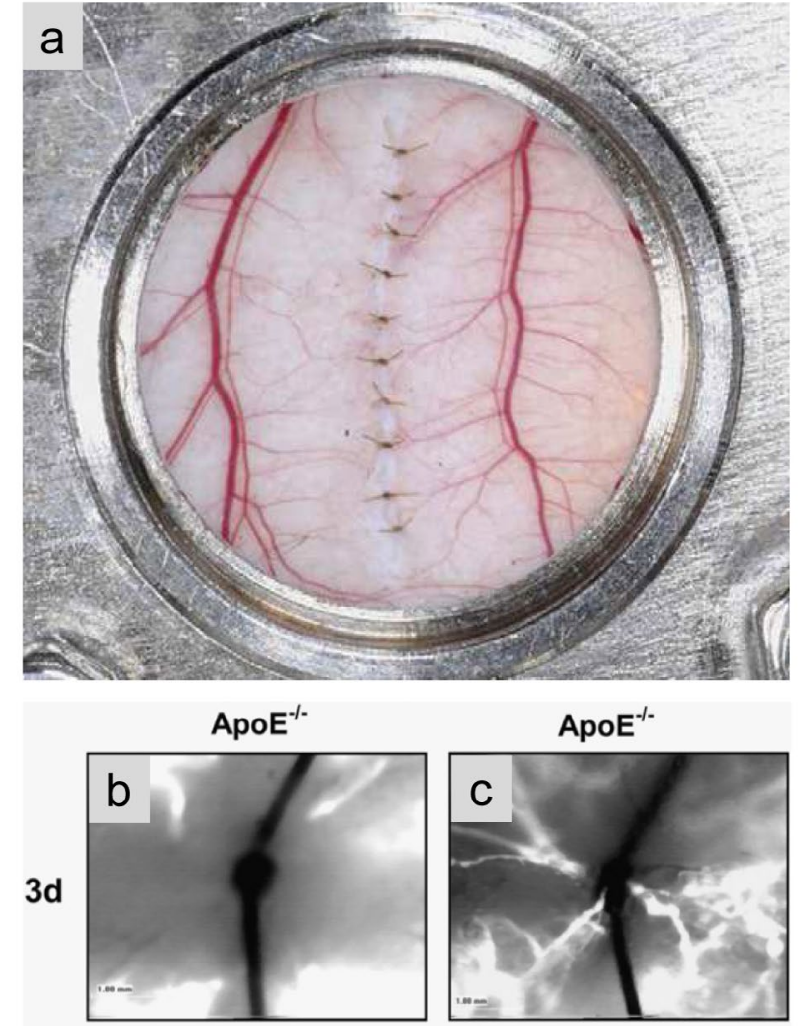

$7 d$
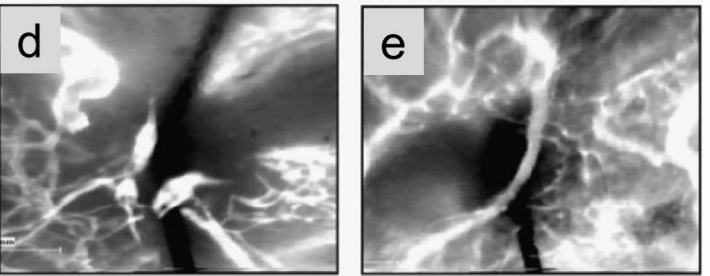

9d

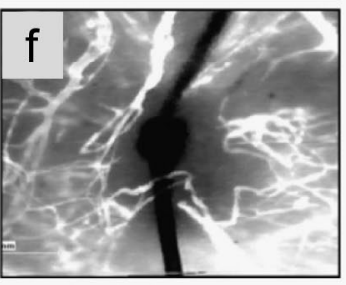

vehicle treatment

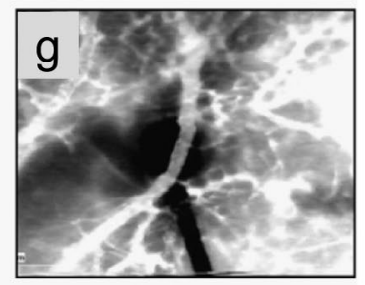

EPO treatment
Fig. 3. Dorsal skinfold chamber model for the study of primary wound healing according to Elsherbiny et al. (2012). (a) Photomacroscopic image of an incisional wound in the centre of the observation window. (b-g) Intravital fluorescence microscopy (contrast enhancement by $5 \%$ FITC-labelled dextran in epiillumination) of incisional wounds in dorsal skinfold chambers of vehicle-treated $(\mathbf{b}, \mathbf{d}, \mathbf{f})$ and EPO-treated ApoE $^{-/-}$mice $(1000 \mathrm{U} / \mathrm{kg}$ body weight i.p.; c,e,g) at day $3(\mathbf{b}, \mathbf{c}), 7$ (d,e) and 9 (f,g) post-wounding. Note the higher microvessel density around the 9/0 Nylon suture (black) in the EPO-treated animal when compared to the control. Reproduced from Elsherbiny et al. (2012) with permission from Elsevier. 
to the wound centre and finally regresses after complete wound closure (Sorg et al., 2007).

In the search for novel therapeutic options to improve wound healing, systemic application of repetitive low doses but especially single high doses of EPO have been shown to improve secondary wound healing in the dorsal skinfold chamber of hairless mice (Sorg et al., 2009). This treatment accelerates wound epithelialisation and stimulates maturation of newly developing microvascular networks. In contrast, repetitive high doses of EPO induce massive erythrocytosis, resulting in rheological malfunction, impaired vessel maturation and delayed wound closure. Another interesting approach to promote dermal regeneration is the systemic pretreatment with unmethylated $\mathrm{CpG}$ oligodeoxynucleotides (ODNs) (Hergert et al., 2013). ODNs stimulate the immune system by binding to Toll-like receptor-9. In healing wounds, this supports the shift from M1-polarised inflammatory macrophages towards regenerative M2-polarised macrophages, attracts fibroblasts and keratinocytes and, thus, improves tissue-remodelling processes and wound epithelialisation.

It is further possible to investigate muscle wound healing in dorsal skinfold chambers by creating lesions of the panniculus carnosus muscle in the centre of the observation window. This approach was used by Machado and Mitchell (2011) to study endothelial barrier function in pre-existing vessels as well as angiogenic plexus and blindended vessels in discrete wounds. They found a relationship between temporal changes in macromolecular flux and the morphology of maturating vascular segments. In addition, they performed longitudinal confocal microscopic analyses of perfused vascular segments to create a mathematical model of angiogenesis during wound healing (Machado et al., 2011). Finally, Langer et al. (2016) reported that vascularisation and closure of panniculus carnosus lesions are affected in diabetic mice when compared to wild-type controls. This study nicely demonstrates that the skinfold chamber model is not only suitable for the testing of novel wound therapies in healthy animals but also to investigate the mechanisms of disturbed wound healing under different pathophysiological conditions by means of appropriate mouse strains.

\section{Dermal substitutes}

The chamber preparation for the analysis of secondary wound healing is also suitable for the evaluation of dermal substitutes and tissue engineered skin. For this purpose, the full-thickness skin wound is usually created with a larger diameter of 6-7 $\mathrm{mm}$ for the press fit implantation of the substitutes (Fig. 2d). Nonetheless, this wound area is still rather small when compared to the common model of dorso-lateral full-thickness wounds without a chamber allowing the assessment of implants with a size of up to $2 \times 3 \mathrm{~cm}$ (Rasmussen et al., 2010). Moreover, the implants can only be analysed throughout an observation period of 2-3 weeks, because the elasticity of the dorsal skinfold decreases over time which can lead to tilting of the chamber and perfusion failure of the tissue. Accordingly, this model can only be used to study the early inflammatory and angiogenic host tissue response to dermal substitutes. This, however, is not necessarily a disadvantage, because under clinical conditions the early vascularisation and incorporation of the implants may particularly determine the quality of healing and the risk of wound infection. Thus, the initial post-implantation phase is also of major interest in preclinical studies. An advantage of the dorsal skinfold chamber model is the fact that the implanted dermal substitutes are protected by the cover glass from exsiccation and manipulation by the animals (Michael et $a l ., 2013 \mathrm{a})$. There is also no need for additional wound dressings and their regular changes, which may markedly affect the incorporation process by damaging the tissue preparation and stressing the animals.

Michael et al. (2013a) implanted a dermal construct comprising a collagen type I gel on top of a Matriderm ${ }^{\circledR}$ layer into $6 \mathrm{~mm}$ full-thickness skin wounds within the observation window of mouse dorsal skinfold chambers. Histological and immunohistochemical analyses after $11 \mathrm{~d}$ revealed that the implants were invaded by fibroblasts and started to epithelialise from the wound edges. However, they did not yet exhibit any ingrowing microvessels. In a follow-up study (Michael et al., 2013b) the Matriderm ${ }^{\circledR}$ layer was coated with 20 layers of fibroblast-containing collagen and 20 layers of keratinocyte-containing collagen by means of laser-assisted bioprinting. The two cell types survived the printing and implantation procedure and markedly contributed to the formation of a multilayered epidermis with an underlying corneal layer and collagen deposition into the matrix. This was associated with an improved vascularisation of the implants. These findings indicate that laser-assisted bioprinting represents a promising approach for the tissue engineering of skin constructs with improved biological properties when compared to cell-free dermal substitutes.

Kijanska et al. (2016) recently used the dorsal skinfold chamber model to analyse in vivo the integration and vascularisation of SERI ${ }^{\circledR}$ Surgical Scaffold, which is a bioresorbable, silk-derived multifilament scaffold for soft tissue support (Gross et al., 2014). By means of immunohistochemical analyses and corrosion casting they found that the scaffold induces an inflammatory host tissue response, which promotes the rapid ingrowth of a vascularised granulation tissue in the scaffold pores. These results are in line with clinical studies reporting an excellent in vivo performance of SERI ${ }^{\circledR}$ Surgical Scaffold in breast reconstruction, circumferential abdominoplasty and lower body lift (Kornstein, 2014; Fine et al., 2015).

\section{Skin grafts}

For the analysis of skin graft revascularisation, a dorsal skinfold chamber is prepared in a first step. After a recovery period of $3 \mathrm{~d}$, the cutis and parts of the subcutis are removed in a circular area of $7 \mathrm{~mm}$ in diameter from the back of the chamber, resulting in a wound bed consisting of panniculus carnosus muscle and subcutaneous tissue (Lindenblatt et al., 2008; Lindenblatt et al., 2010) (Figs. 2e and 5a-d). A full-thickness skin graft of identical size is then excised 

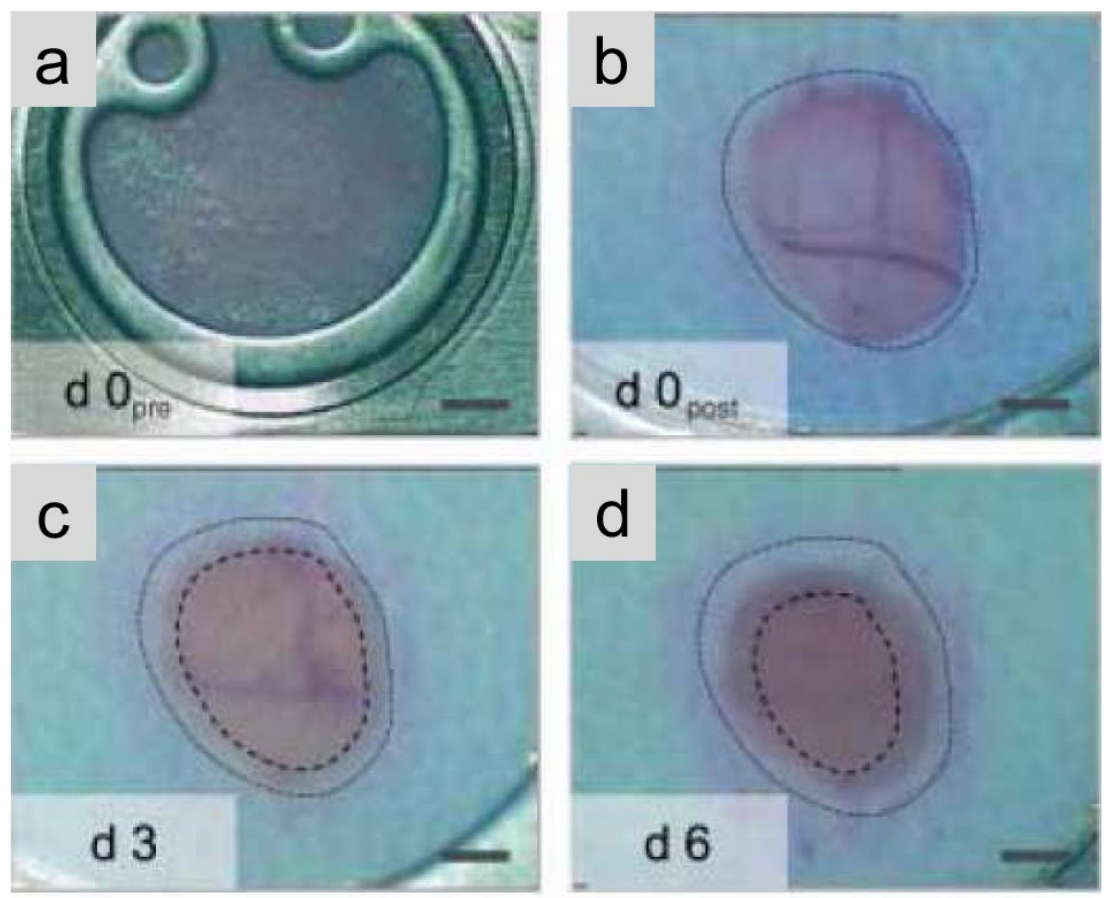

Fig. 4. Dorsal skinfold chamber model for the study of secondary wound healing according to Sorg et al. (2007). Photomacroscopic images of the skinfold chamber prior to day $0_{\text {pre }}$ (a) and directly after wounding $0_{\text {post }}(\mathbf{b})$, as well as at day $3(\mathbf{c}), 6(\mathbf{d}), 9$ (e) and 12 (f), displaying the continuous process of wound closure with complete epithelialisation at day 12 (dotted lines: wound border; broken lines: border of non-epithelialised wound area). Reproduced from Sorg et al. (2007) with permission from John Wiley and Sons.
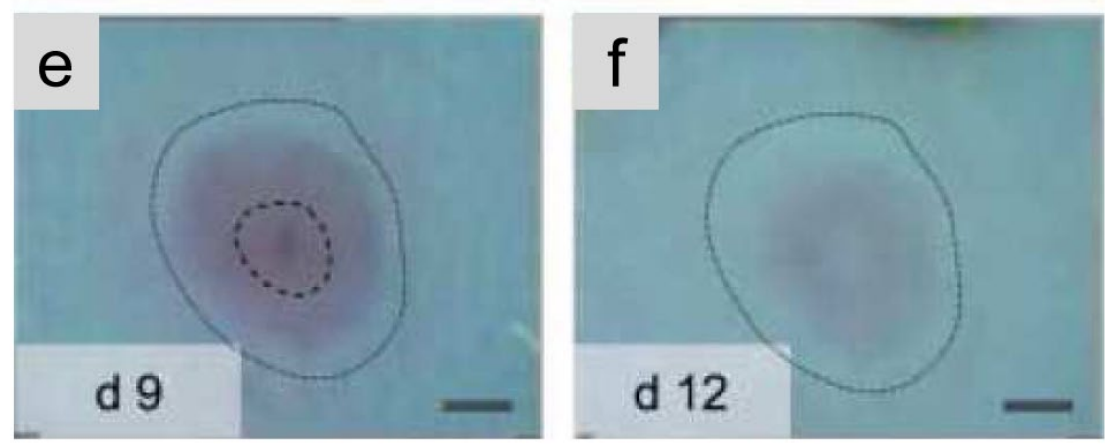

from the groin of the animal and fixed in the defect with polypropylene 8-0 sutures. The observation window of the back side is finally closed with a cover glass.

The major advantage of this modified dorsal skinfold chamber model is the fact that it enables simultaneous intravital fluorescent microscopic analyses of the wound bed from the front of the chamber and the skin graft from the back of the chamber during the first $10 \mathrm{~d}$ after engraftment (Lindenblatt et al., 2008). Thus, it allows not only the visualisation of typical morphological characteristics of the angiogenic process, such as the formation of capillary buds and sprouts, but also the assessment of blood perfusion in individual microvessels of the grafts and the host tissue. Lindenblatt et al. (2008) could demonstrate that skin grafts induce angiogenesis in the wound bed with ingrowth of newly developing microvessels into the grafts and subsequent connection to the existing vasculature after 3 d. Knapik et al. (2012) showed that this connection is mediated by matrix metalloproteinase MT1-MMP, which is specifically expressed at the tips of ingrowing sprouts, stimulating their proliferation and lysing the existing graft capillaries in order to connect to them. The onset of blood perfusion, in turn, induces a temporary angiogenic response within the grafts' capillaries between days 3 and 8 . This most likely represents a reaction to accumulating angiogenic growth factors in the hypoxic tissue during the reperfusion phase (Lindenblatt et al., 2010). By suturing skin grafts from transgenic green fluorescent protein (GFP)-positive donor mice into dorsal skinfold chambers of GFP-negative wild-type mice and vice versa, Calcagni et al. (2011) further found that $68 \%$ of existing graft capillaries are replaced over time by ingrowing vessels from the wound bed using the old vessels as channels. Accordingly, they suggested that comparably to skin grafts, fabricated skin substitutes should also provide preformed vascular channels to improve their vascularisation after implantation.

In plastic surgery, surplus harvested skin grafts are usually stored at $4-6{ }^{\circ} \mathrm{C}$ in saline for several days before transplantation. Knapik et al. (2014) analysed how this type of preservation influences the engraftment of freshly harvested human full-thickness and split-thickness skin grafts in severe combined immunodeficiency (SCID) mice. They found that host capillary ingrowth and graft vessel degeneration were not affected by cold storage. However, the warming up of the grafts in the wound bed caused significant tissue injury, which was not observed prior to transplantation. These findings indicate that skin tissue is protected from damage under cold conditions, most likely due to a reduced cell metabolism. Nonetheless, tissue damage is higher in cold stored skin grafts, which is disclosed in the rewarming phase after transplantation. 

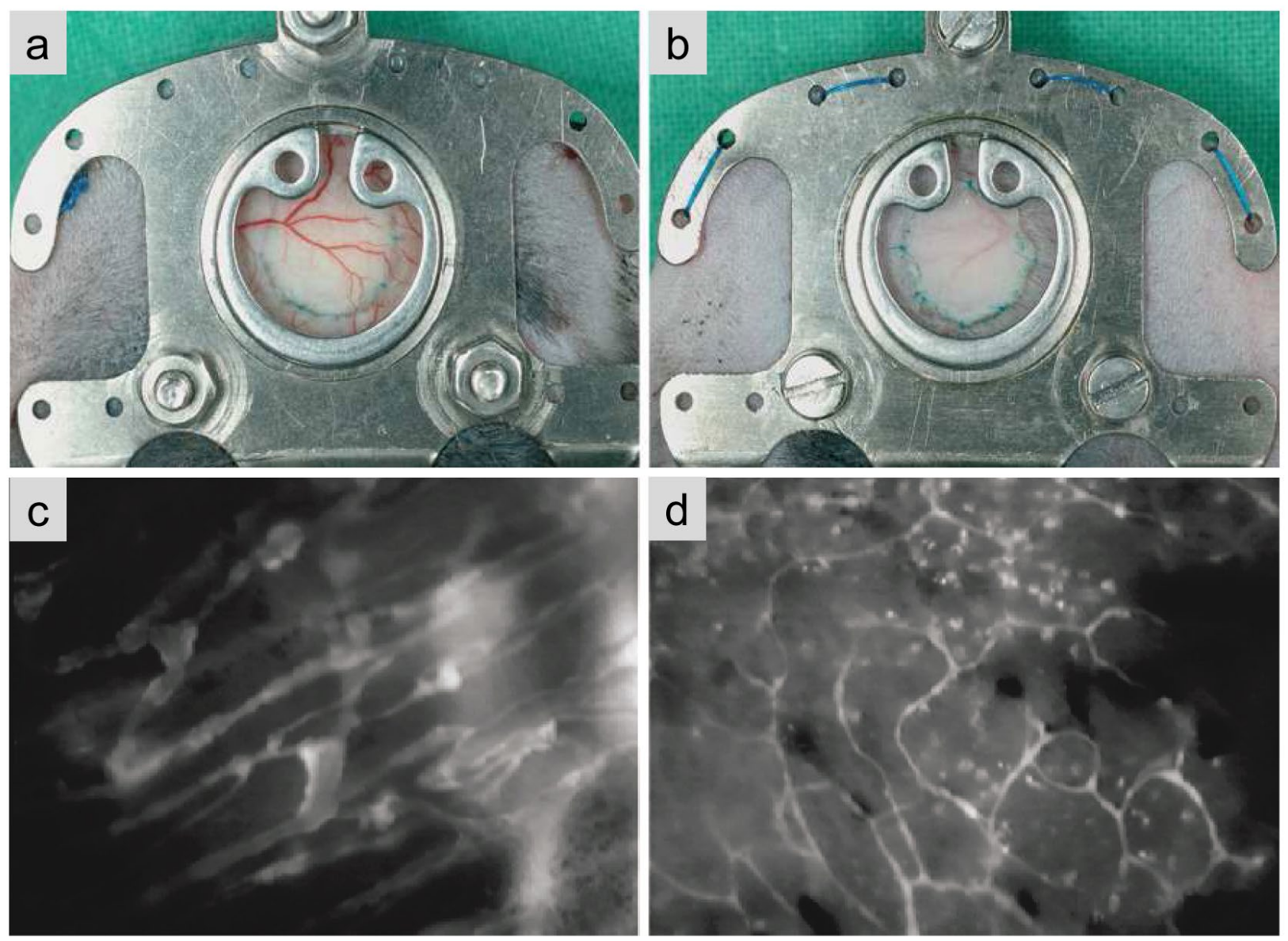

Fig. 5. Dorsal skinfold chamber model for the study of skin graft revascularisation according to Lindenblatt et al. (2010). (a) From the front of the chamber, the muscle wound bed (panniculus carnosus) and the larger subcutaneous vessels are visible. (b) The microcirculation of the skin graft can be visualised from the back of the chamber. (c,d) Intravital fluorescence microscopy (contrast enhancement by $5 \%$ FITC-labelled dextran in epi-illumination) shows a strong angiogenic response of the wound bed after $48 \mathrm{~h}(\mathbf{c})$, resulting in reperfusion of the graft capillaries after $72 \mathrm{~h}$ (d). Reproduced from Lindenblatt et al. (2010) with permission from Wolters Kluwer Health, Inc.

\section{Myocutaneous flaps}

Ichioka et al. (2002) demonstrated for the first time the suitability of skinfold chambers for the analysis of flap microcirculation. They implanted a newly designed small chamber in a large bipedicled island flap on the dorsum of mice. To induce partial flap necrosis, the vascular pedicles of the island flap were temporarily clamped to induce global ischaemia and reperfusion. In contrast, Harder et al. (2004) combined the mouse dorsal skinfold chamber with a laterally based random pattern flap with a width-to-length ratio of $15 \times 11 \mathrm{~mm}$. Importantly, this flap undergoes persistent ischaemia and spontaneously develops $50 \%$ necrosis if kept untreated. Accordingly, it has been frequently used to study pathological mechanisms in critically ischaemic myocutaneous tissue and to evaluate novel therapeutic strategies to improve flap perfusion and survival (Harder et al., 2014). For this purpose, repetitive microcirculatory in vivo measurements in different regions of the flap can be combined with immunohistochemical and molecular biological analyses of the flap tissue.

For the preparation of the random pattern flap, the back of the animal is depilated and the chamber's back side frame is temporarily placed on the double-layered skinfold to outline the flap on the skin with its distal $2 \mathrm{~mm}$ extending to the contralateral side (Fig. 6a). The deep circumflex iliac artery and the lateral thoracic artery are then transected during the elevation of the flap (Fig. 6b). Subsequently, the top edge of the flap, consisting of cutis, subcutis and panniculus carnosus muscle, is fixed to the chamber's back side frame (Fig. 6c). The lateral sides are sutured back to the surrounding skinfold (Fig. 6d). In addition, the overlaying skin layer of the opposite side of the flap is removed, which allows the direct visualisation onto the elevated flap tissue (Fig. 6d). Finally, the preparation is covered with the front side frame of the chamber (Fig. 6 e) and the observation window is closed with a cover glass that provides continuous access to the flap tissue for repetitive intravital microscopy (Figs. $2 \mathbf{f}$ and $6 \mathbf{f}$ ).

Analyses of the microcirculation and partial oxygen tension in different zones of the myocutaneous flap revealed that the critical ischaemia-induced necrosis does not demarcate sharply from the adequately perfused tissue at the flap basis (Harder et al., 2005a). Between the two zones a fringe of tissue with vascular remodelling develops a distally adjacent falx lunatica lacking nutritive 

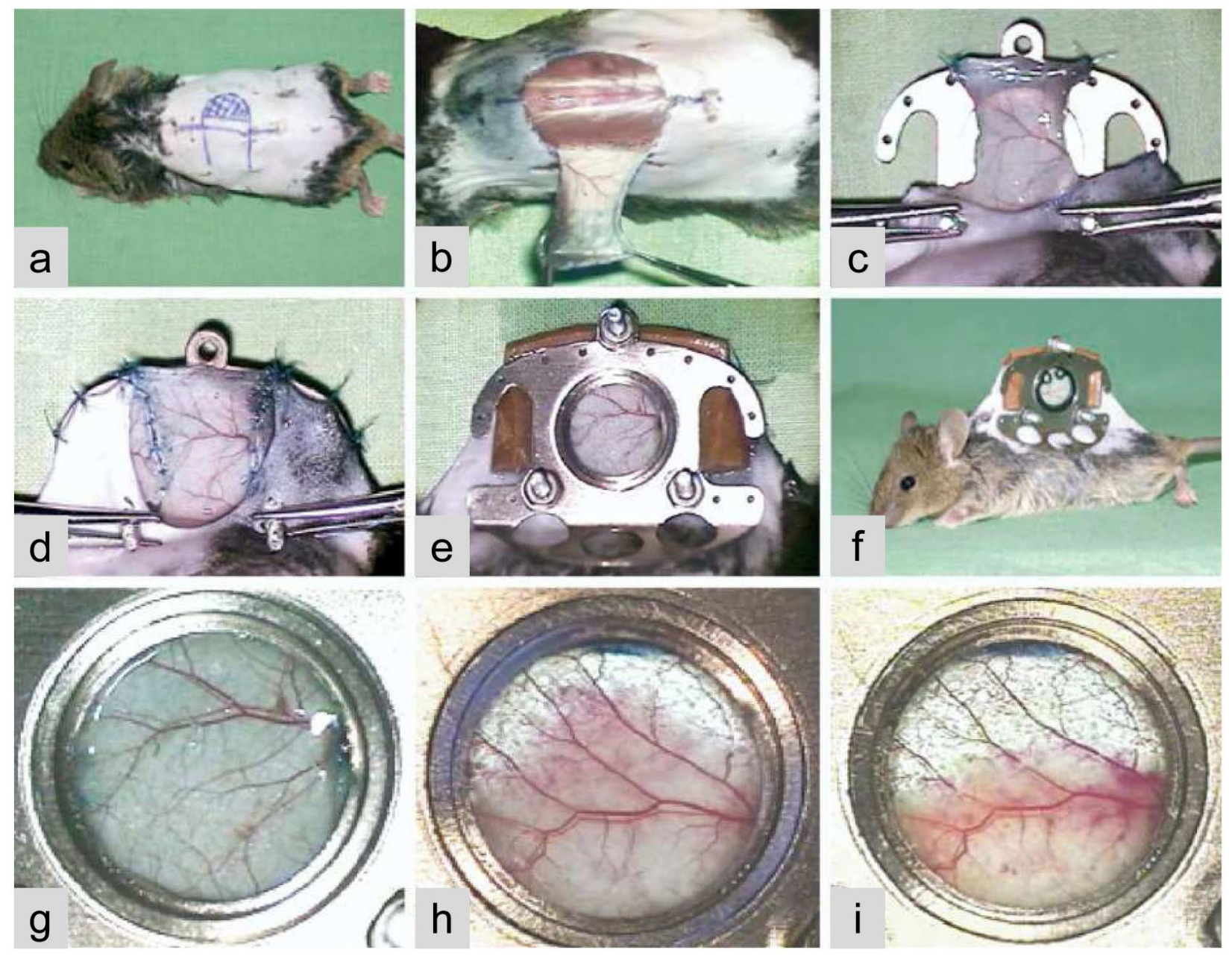

Fig. 6. Dorsal skinfold chamber model for the study of myocutaneous flaps according to Harder et al. (2004). (a) Flap outlined on the skin (width/length $15 \mathrm{~mm} / 11 \mathrm{~mm}$ ) with its distal $2 \mathrm{~mm}$ extending to the contralateral side. To study the back side of the flap tissue through the observation window, additional tissue (hatched area) has to be removed. (b) Elevation of the laterally based flap with a distinct, however randomly arranged vascular architecture. (c,d) Flap extended on the back side of the frame (c) sutured back into the dorsal skin (d) to guarantee tightness. (e) Fully mounted chamber with cover glass and brown sealing band exceeding the device both laterally and on top immediately after the operation. (f) Mouse after implantation of dorsal skinfold chamber according to controls without flap elevation. (g) Observation window instantly after the preparation, displaying an intact microvasculature (control animal). (h,j) Observation window at day 1 (h) and day 3 (j) after flap elevation, demonstrating a clear line of demarcation which moves toward the flap's base. Reproduced from Harder et al. (2004) with permission from Elsevier.

blood perfusion and solely surviving by oxygen diffusion (Harder et al., 2005a). Additional studies have shown that the perfusion and survival of the flap can be improved by different therapeutic approaches. These include local heat preconditioning (Harder et al., 2005b), selective blockade of endothelin-B receptor (Wettstein et al., 2007) as well as pharmacological treatment with EPO (Rezaeian et al., 2008; Harder et al., 2009; Rezaeian et al., 2013), n-acetylcysteine (Bächle et al., 2011) and ghrelin (Rezaeian et al., 2012). Promising results of these preclinical studies have encouraged the conduction of first translational studies in the clinical setting. For instance, Mehta et al. (2013) demonstrated in a prospective nonrandomised trial including 50 patients that local heat preconditioning reduces skin necrosis and hospitalisation length following skin sparing mastectomy and immediate breast reconstruction.

\section{Conclusions}

The herein described studies indicate that the dorsal skinfold chamber is a versatile tool for regenerative medicine research. The major advantage of this model is the direct access to the analysed tissues and implants, which are protected from manipulation by the animals within the observation window. In combination with intravital fluorescence microscopic techniques this allows repetitive, non-invasive analyses of dynamic regenerative processes with quantitative measurements of functional parameters such as microvascular perfusion or leukocyte-endothelial cell interactions with a high spatial and temporal resolution. However, the analyses are restricted to an observation period of 2-3 weeks after chamber preparation, because the elasticity of the dorsal skinfold is lost over time. Moreover, the imaging quality within the observation window may 
progressively decrease due to repetitive applications of fluorescent dyes and their increased vascular leakage under angiogenic or inflammatory conditions. Accordingly, the dorsal skinfold chamber is particularly a model for the detailed analysis of early biological events, which crucially determine the long-term outcome of regenerative processes such as biomaterial integration (Sclafani et al., 1997; Naik et al., 2007). Due to the fixation of the skin tissue between the two chamber frames, it is also well suited for the study of wound healing, engraftment of dermal substitutes and flap survival without contraction of the underlying panniculus carnosus muscle, which represents a typical pitfall of other models in loose-skinned rodents.

It has to be further considered that the given dimensions of the dorsal skinfold chamber markedly limit the size of the analysed tissues and implants, which are usually much larger in the clinical setting. On the other hand, this allows their examination under standardised conditions without biases due to individual size adjustments. Moreover, they can be manipulated in the chamber without affecting the general condition of the animal. This may be particularly advantageous for studies focusing on hypo- and hyperthermic preconditioning or the evaluation of pharmacological compounds, which can be locally administered into the observation window. By pressing a silicone pad on the cutis of the back side of the window (Schäfer et al., 2005; Contaldo et al., 2007), it may even be possible to analyse biomaterial implants under static mechanical load or to expose the regenerating tissue inside the chamber to clearly defined time periods of ischaemia and reperfusion.

Taken together, these characteristics of the dorsal skinfold chamber model offer many possibilities to study dynamic regenerative processes under defined experimental conditions. Hence, this preclinical model represents a versatile tool to develop novel therapeutic strategies in the field of tissue engineering and regenerative medicine.

\section{Acknowledgements}

There was no specific funding of this review article.

\section{References}

Abshagen K, Schrodi I, Gerber T, Vollmar B (2009) In vivo analysis of biocompatibility and vascularisation of the synthetic bone grafting substitute NanoBone. J Biomed Mater Res A 91: 557-566.

Ampofo E, Müller I, Dahmke IN, Eichler H, Montenarh M, Menger MD, Laschke MW (2015a) Role of protein kinase CK2 in the dynamic interaction of platelets, leukocytes and endothelial cells during thrombus formation. Thromb Res 136: 996-1006.

Ampofo E, Rudzitis-Auth J, Dahmke IN, Rössler OG, Thiel G, Montenarh M, Menger MD, Laschke MW (2015b) Inhibition of protein kinase CK2 suppresses tumor necrosis factor (TNF)- $\alpha$-induced leukocyte-endothelial cell interaction. Biochim Biophys Acta 1852: 2123-2136.
Ampofo E, Widmaier D, Montenarh M, Menger MD, Laschke MW (2016) Protein kinase CK2 regulates leukocyte-endothelial cell jnteractions during ischemia and reperfusion in striated skin muscle. Eur Surg Res 57: 111-124.

Anderson JM, Rodriguez A, Chang DT (2008) Foreign body reaction to biomaterials. Semin Immunol 20: 86-100.

Baron VT, Welsh J, Abedinpour P, Borgström P (2011) Intravital microscopy in the mouse dorsal chamber model for the study of solid tumors. Am J Cancer Res 1: 674-686.

Bächle AC, Mörsdorf P, Rezaeian F, Ong MF, Harder Y, Menger MD (2011) N-acetylcysteine attenuates leukocytic inflammation and microvascular perfusion failure in critically ischemic random pattern flaps. Microvasc Res 82: 28-34.

Benavides F, Oberyszyn TM, VanBuskirk AM, Reeve VE, Kusewitt DF (2009) The hairless mouse in skin research. J Dermatol Sci 53: 10-18.

Bordel R, Laschke MW, Menger MD, Vollmar B (2006) Nicotine does not affect vascularisation but inhibits growth of freely transplanted ovarian follicles by inducing granulosa cell apoptosis. Hum Reprod 21: 610-617.

Boulaftali Y, Lamrani L, Rouzaud MC, Loyau S, Jandrot-Perrus M, Bouton MC, Ho-Tin-Noé B (2012) The mouse dorsal skinfold chamber as a model for the study of thrombolysis by intravital microscopy. Thromb Haemost 107: 962-971.

Calcagni M, Althaus MK, Knapik AD, Hegland N, Contaldo C, Giovanoli P, Lindenblatt N (2011) In vivo visualization of the origination of skin graft vasculature in a wild-type/GFP crossover model. Microvasc Res 82: 237-245.

Contaldo C, Meier C, Elsherbiny A, Harder Y, Trentz O, Menger MD, Wanner GA (2007) Human recombinant erythropoietin protects the striated muscle microcirculation of the dorsal skinfold from postischemic injury in mice. Am J Physiol Heart Circ Physiol 293: H274-H283.

Contaldo C, Högger DC, Khorrami Borozadi M, Stotz M, Platz U, Forster N, Lindenblatt N, Giovanoli P (2012) Radial pressure waves mediate apoptosis and functional angiogenesis during wound repair in ApoE deficient mice. Microvasc Res 84: 24-33.

de Miranda ML, Pereira SJ, Santos AO, Villela NR, Kraemer-Aguiar LG, Bouskela E (2015) Milrinone attenuates arteriolar vasoconstriction and capillary perfusion deficits on endotoxemic hamsters. PLoS One 10: e0117004.

Davidson JM, Yu F, Opalenik SR (2013) Splinting strategies to overcome confounding wound contraction in experimental animal models. Adv Wound Care (New Rochelle) 2: 142-148.

Debergh I, Van Damme N, Pattyn P, Peeters M, Ceelen WP (2010) The low-molecular-weight heparin, nadroparin, inhibits tumour angiogenesis in a rodent dorsal skinfold chamber model. Br J Cancer 102: 837-843.

Druecke D, Langer S, Lamme E, Pieper J, Ugarkovic M, Steinau HU, Homann HH (2004) Neovascularisation of poly(ether ester) block-copolymer scaffolds in vivo: longterm investigations using intravital fluorescent microscopy. J Biomed Mater Res A 68: 10-18. 
Ehrmantraut S, Naumann A, Willnecker V, Akinyemi S, Körbel C, Scheuer C, Meyer-Lindenberg A, Menger MD, Laschke MW (2012) Vitalization of porous polyethylene (Medpor ${ }^{\circledR}$ ) with chondrocytes promotes early implant vascularisation and incorporation into the host tissue. Tissue Eng Part A 18: 1562-1572.

Elsherbiny A, Högger DC, Borozadi MK, Schmidt CA, Plock J, Largo RD, Lindenblatt N, Giovanoli P, Contaldo C (2012) EPO reverses defective wound repair in hypercholesterolaemic mice by increasing functional angiogenesis. J Plast Reconstr Aesthet Surg 65: 1559-1568.

Feng D, Menger MD, Wang H, Laschke MW (2014) Luminal epithelium in endometrial fragments affects their vascularisation, growth and morphological development into endometriosis-like lesions in mice. Dis Model Mech 7: 225-232.

Fine NA, Lehfeldt M, Gross JE, Downey S, Kind GM, Duda G, Kulber D, Horan R, Ippolito J, Jewell M (2015) SERI surgical scaffold, prospective clinical trial of a silk-derived biological scaffold in two-stage breast reconstruction: 1-year data. Plast Reconstr Surg 135: 339351.

Franke N, Endrich B, Laubenthal H, Peter K, Messmer K (1982) The effect of pentobarbital on the microcirculation of skeletal muscles and the subcutis. An animal-experimental study. Anasth Intensivther Notfallmed 17: 11-14.

Franke N, Endrich B (1983) Effects of halothane and enflurane on the microcirculation. Anasth Intensivther Notfallmed 18: 285-290.

Funk W, Endrich B, Messmer K, Intaglietta M (1983) Spontaneous arteriolar vasomotion as a determinant of peripheral vascular resistance. Int J Microcirc Clin Exp 2: 11-25.

Funk W, Endrich B, Messmer K (1986) A novel method for follow-up studies of the microcirculation in non-malignant tissue implants. Res Exp Med (Berl) 186: 259-270.

Garrido-Martin EM, Nguyen HL, Cunningham TA, Choe SW, Jiang Z, Arthur HM, Lee YJ, Oh SP (2014) Common and distinctive pathogenetic features of arteriovenous malformations in hereditary hemorrhagic telangiectasia 1 and hereditary hemorrhagic telangiectasia 2 animal models - brief report. Arterioscler Thromb Vasc Biol 34: 2232-2236.

Gerstberger R, Meyer JU, Rettig R, Printz M, Intaglietta M (1988) Regulatory role of vasoactive peptides in subcutaneous skin microcirculation of the hamster. Int $\mathrm{J}$ Microcirc Clin Exp 7: 3-14.

Ghanaati S, Webber MJ, Unger RE, Orth C, Hulvat JF, Kiehna SE, Barbeck M, Rasic A, Stupp SI, Kirkpatrick CJ (2009) Dynamic in vivo biocompatibility of angiogenic peptide amphiphile nanofibers. Biomaterials 30: 62026212.

Gross JE, Horan RL, Gaylord M, Olsen RE, McGill LD, García-López JM, Biber K, Barnico K, Toponarski I, Altman G (2014) An evaluation of SERI surgical scaffold for soft-tissue support and repair in an ovine model of two-stage breast reconstruction. Plast Reconstr Surg 134: 700e-704e.
Hallock GG, Morris SF (2011) Skin grafts and local flaps. Plast Reconstr Surg 127: 5e-22e.

Harder Y, Amon M, Erni D, Menger MD (2004) Evolution of ischemic tissue injury in a random pattern flap: a new mouse model using intravital microscopy. J Surg Res 121: 197-205.

Harder Y, Amon M, Georgi M, Banic A, Erni D, Menger MD (2005a) Evolution of a "falx lunatica" in demarcation of critically ischemic myocutaneous tissue. Am J Physiol Heart Circ Physiol 288: H1224-1232.

Harder Y, Amon M, Schramm R, Georgi M, Banic A, Erni D, Menger MD (2005b) Heat shock preconditioning reduces ischemic tissue necrosis by heat shock protein (HSP)-32-mediated improvement of the microcirculation rather than induction of ischemic tolerance. Ann Surg 242: 869-878.

Harder Y, Amon M, Schramm R, Contaldo C, Metzkow E, Matzen A, Rücker M, Vollmar B, Menger MD (2009) Erythropoietin reduces necrosis in critically ischemic myocutaneous tissue by protecting nutritive perfusion in a dose-dependent manner. Surgery 145: 372-383.

Harder Y, Schmauss D, Wettstein R, Egaña JT, Weiss F, Weinzierl A, Schuldt A, Machens HG, Menger MD, Rezaeian F (2014) Ischemic tissue injury in the dorsal skinfold chamber of the mouse: a skin flap model to investigate acute persistent ischemia. J Vis Exp 93: e51900.

Hergert B, Grambow E, Butschkau A, Vollmar B (2013) Effects of systemic pretreatment with CpG oligodeoxynucleotides on skin wound healing in mice. Wound Repair Regen 21: 723-729.

Hillgruber C, Steingräber AK, Pöppelmann B, Denis CV, Ware J, Vestweber D, Nieswandt B, Schneider SW, Goerge T (2014) Blocking von Willebrand factor for treatment of cutaneous inflammation. J Invest Dermatol 134: 77-86.

Hoffmann JN, Vollmar B, Laschke MW, Inthorn D, Fertmann J, Schildberg FW, Menger MD (2004) Microhemodynamic and cellular mechanisms of activated protein $\mathrm{C}$ action during endotoxemia. Crit Care Med 32: 1011-1017.

Horan MP, Quan N, Subramanian SV, Strauch AR, Gajendrareddy PK, Marucha PT (2005) Impaired wound contraction and delayed myofibroblast differentiation in restraint-stressed mice. Brain Behav Immun 19: 207-216.

Ichioka S, Minh TC, Shibata M, Nakatsuka T, Sekiya N, Ando J, Harii K (2002) In vivo model for visualizing flap microcirculation of ischemia-reperfusion. Microsurgery 22: 304-310.

Kampmann A, Lindhorst D, Schumann P, Zimmerer R, Kokemüller H, Rücker M, Gellrich NC, Tavassol F (2013) Additive effect of mesenchymal stem cells and VEGF to vascularisation of PLGA scaffolds. Microvasc Res 90: 71-79.

Kijanska M, Marmaras A, Hegglin A, Kurtcuoglu V, Giovanoli P, Lindenblatt N (2016) In vivo characterization of the integration and vascularisation of a silk-derived surgical scaffold. J Plast Reconstr Aesthet Surg, 69:11411150.

Knapik A, Hegland N, Calcagni M, Althaus M, Vollmar B, Giovanoli P, Lindenblatt N (2012) Metalloproteinases 
facilitate connection of wound bed vessels to pre-existing skin graft vasculature. Microvasc Res 84: 16-23.

Knapik A, Kornmann K, Kerl K, Calcagni M, Schmidt CA, Vollmar B, Giovanoli P, Lindenblatt N (2014) In vivo evaluation of wound bed reaction and graft performance after cold skin graft storage: new targets for skin tissue engineering. J Burn Care Res 35: e187-196.

Kornstein A (2014) SERI surgical scaffold as an adjunct for circumferential abdominoplasty and lower body lift. Plast Reconstr Surg Glob Open 2: e244.

Krieger JR, Ogle ME, McFaline-Figueroa J, Segar CE, Temenoff JS, Botchwey EA (2016) Spatially localized recruitment of anti-inflammatory monocytes by SDF$1 \alpha$-releasing hydrogels enhances microvascular network remodeling. Biomaterials 77: 280-290.

Kuehnl A, Pelisek J, Ring A, Spindler N, Hatz R, Jauch KW, Eckstein HH, Langer S (2013) C-type natriuretic peptide slows down wound healing but promotes angiogenesis in SKH1-hr hairless mice. Int Wound J 10: 425-430.

Langer S, Beescho C, Ring A, Dorfmann O, Steinau HU, Spindler N (2016) A new in vivo model using a dorsal skinfold chamber to investigate microcirculation and angiogenesis in diabetic wounds. GMS Interdiscip Plast Reconstr Surg DGPW 18: Doc09.

Laschke MW, Augustin VA, Sahin F, Anschütz D, Metzger W, Scheuer C, Bischoff M, Aktas C, Menger MD (2016) Surface modification by plasma etching impairs early vascularisation and tissue incorporation of porous polyethylene $\left(\right.$ Medpor $^{\circledR}$ ) implants. J Biomed Mater Res B Appl Biomater, in press.

Laschke MW, Augustin V, Kleer S, Tschernig T, Menger MD (2014) Locally applied macrophage-activating lipopeptide-2 (MALP-2) promotes early vascularisation of implanted porous polyethylene $\left(\right.$ Medpor $\left.^{\circledR}\right)$. Acta Biomater 10: 4661-4669.

Laschke MW, Kleer S, Scheuer C, Schuler S, Garcia P, Eglin D, Alini M, Menger MD (2012) Vascularisation of porous scaffolds is improved by incorporation of adipose tissue-derived microvascular fragments. Eur Cell Mater 24: 266-277.

Laschke MW, Menger MD (2007) In vitro and in vivo approaches to study angiogenesis in the pathophysiology and therapy of endometriosis. Hum Reprod Update 13: 331-342.

Laschke MW, Menger MD (2015) Adipose tissuederived microvascular fragments: natural vascularisation units for regenerative medicine. Trends Biotechnol 33: 442-448.

Laschke MW, Menger MD (2016) Prevascularisation in tissue engineering: Current concepts and future directions. Biotechnol Adv 34: 112-121.

Laschke MW, Schank TE, Scheuer C, Kleer S, Schuler S, Metzger W, Eglin D, Alini M, Menger MD (2013) Threedimensional spheroids of adipose-derived mesenchymal stem cells are potent initiators of blood vessel formation in porous polyurethane scaffolds. Acta Biomater 9: 68766884.

Laschke MW, Strohe A, Menger MD, Alini M, Eglin D (2010) In vitro and in vivo evaluation of a novel nanosize hydroxyapatite particles/poly(ester-urethane) composite scaffold for bone tissue engineering. Acta Biomater 6: 2020-2027.

Laschke MW, Vollmar B, Menger MD (2011) The dorsal skinfold chamber: window into the dynamic interaction of biomaterials with their surrounding host tissue. Eur Cell Mater 22: 147-164.

Laschke MW, Witt K, Pohlemann T, Menger MD (2007) Injectable nanocrystalline hydroxyapatite paste for bone substitution: in vivo analysis of biocompatibility and vascularisation. J Biomed Mater Res B Appl Biomater 82: 494-505.

Lindenblatt N, Calcagni M, Contaldo C, Menger MD, Giovanoli P, Vollmar B (2008) A new model for studying the revascularisation of skin grafts in vivo: the role of angiogenesis. Plast Reconstr Surg 122: 1669-1680.

Lindenblatt N, Platz U, Althaus M, Hegland N, Schmidt CA, Contaldo C, Vollmar B, Giovanoli P, Calcagni M (2010) Temporary angiogenic transformation of the skin graft vasculature after reperfusion. Plast Reconstr Surg 126: $61-70$.

Lindhorst D, Tavassol F, von See C, Schumann P, Laschke MW, Harder Y, Bormann KH, Essig H, Kokemüller H, Kampmann A, Voss A, Mülhaupt R, Menger MD, Gellrich NC, Rücker M (2010) Effects of VEGF loading on scaffold-confined vascularisation. J Biomed Mater Res A 95: 783-792.

Machado MJ, Mitchell CA(2011) Temporal changes in microvessel leakiness during wound healing discriminated by in vivo fluorescence recovery after photobleaching. J Physiol 589: 4681-4696.

Machado MJ, Watson MG, Devlin AH, Chaplain MA, McDougall SR, Mitchell CA (2011) Dynamics of angiogenesis during wound healing: a coupled in vivo and in silico study. Microcirculation 18: 183-197.

Menger MD, Laschke MW, Vollmar B (2002) Viewing the microcirculation through the window: some twenty years experience with the hamster dorsal skinfold chamber. Eur Surg Res 34: 83-91.

Menger MD, Laschke MW, Amon M, Schramm R, Thorlacius H, Rücker M, Vollmar B (2003) Experimental models to study microcirculatory dysfunction in muscle ischemia-reperfusion and osteomyocutaneous flap transfer. Langenbecks Arch Surg 388: 281-290.

Mehta S, Rolph R, Cornelius V, Harder Y, Farhadi $\mathrm{J}$ (2013) Local heat preconditioning in skin sparing mastectomy: a pilot study. J Plast Reconstr Aesthet Surg 66: 1676-1682.

Michael S, Sorg H, Peck CT, Reimers K, Vogt PM (2013a) The mouse dorsal skin fold chamber as a means for the analysis of tissue engineered skin. Burns 39: 82-88.

Michael S, Sorg H, Peck CT, Koch L, Deiwick A, Chichkov B, Vogt PM, Reimers K (2013b) Tissue engineered skin substitutes created by laser-assisted bioprinting form skin-like structures in the dorsal skin fold chamber in mice. PLoS One 8: e57741.

Naik MN, Murthy RK, Honavar SG (2007) Comparison of vascularisation of Medpor and Medpor-Plus orbital implants: a prospective, randomized study. Ophthal Plast Reconstr Surg 23: 463-467.

Nenicu A, Körbel C, Gu Y, Menger MD, Laschke MW (2014) Combined blockade of angiotensin II type 
1 receptor and activation of peroxisome proliferatoractivated receptor- $\gamma$ by telmisartan effectively inhibits vascularisation and growth of murine endometriosis-like lesions. Hum Reprod 29: 1011-1024.

Ortiz D, Barros M, Yan S, Cabrales P (2014) Resuscitation from hemorrhagic shock using polymerized hemoglobin compared to blood. Am J Emerg Med 32: 248-255.

Pappelbaum KI, Gorzelanny C, Grässle S, Suckau J, Laschke MW, Bischoff M, Bauer C, Schorpp-Kistner M, Weidenmaier C, Schneppenheim R, Obser T, Sinha B, Schneider SW (2013) Ultralarge von Willebrand factor fibers mediate luminal Staphylococcus aureus adhesion to an intact endothelial cell layer under shear stress. Circulation 128: 50-59.

Rasmussen CA, Gibson AL, Schlosser SJ, Schurr MJ, Allen-Hoffmann BL (2010) Chimeric composite skin substitutes for delivery of autologous keratinocytes to promote tissue regeneration. Ann Surg 251: 368-376.

Reinke JM, Sorg H (2012) Wound repair and regeneration. Eur Surg Res 49: 35-43.

Rezaeian F, Wettstein R, Amon M, Scheuer C, Schramm R, Menger MD, Pittet B, Harder Y (2008) Erythropoietin protects critically perfused flap tissue. Ann Surg 248: 919929.

Rezaeian F, Wettstein R, Scheuer C, Bäumker K, Bächle A, Vollmar B, Menger MD, Harder Y (2012) Ghrelin protects musculocutaneous tissue from ischemic necrosis by improving microvascular perfusion. Am J Physiol Heart Circ Physiol 302: H603-610.

Rezaeian F, Wettstein R, Scheuer C, Schenck TL, Egaña JT, Machens HG, Menger MD, Harder Y (2013) Long-term preconditioning with erythropoietin reduces ischemiainduced skin necrosis. Microcirculation 20: 693-702.

Ring A, Steinstraesser L, Muhr G, Steinau HU, Hauser J, Langer S (2007) Improved neovascularisation of PEGT/PBT copolymer matrices in response to surface modification by biomimetic coating. Eur Surg Res 39: 75-81.

Ring A, Tilkorn D, Ottomann C, Geomelas M, Steinstraesser L, Langer S, Goertz O (2011a) Intravital monitoring of microcirculatory and angiogenic response to lactocapromer terpolymer matrix in a wound model. Int Wound J 8: 112-117.

Ring A, Tilkorn DJ, Goertz O, Langer S, Schaffran A, Awakowicz P, Hauser J (2011b) Surface modification by glow discharge gasplasma treatment improves vascularisation of allogenic bone implants. J Orthop Res 29: $1237-1244$.

Rouwkema J, Khademhosseini A (2016) Vascularisation and angiogenesis in tissue engineering: beyond creating static networks. Trends Biotechnol 34: 733-745.

Rücker M, Laschke MW, Junker D, Carvalho C, Schramm A, Mülhaupt R, Gellrich NC, Menger MD (2006) Angiogenic and inflammatory response to biodegradable scaffolds in dorsal skinfold chambers of mice. Biomaterials 27: 5027-5038.

Rücker M, Laschke MW, Junker D, Carvalho C, Tavassol F, Mülhaupt R, Gellrich NC, Menger MD (2008) Vascularisation and biocompatibility of scaffolds consisting of different calcium phosphate compounds. J Biomed Mater Res A 86: 1002-1011.

Schäfer SC, Sehrt DN, Kamler M, Jakob H, Lehr HA (2005) Paradoxical attenuation of leukocyte rolling in response to ischemia-reperfusion and extracorporeal blood circulation in inflamed tissue. Am J Physiol Heart Circ Physiol 289: H330-335.

Schumann P, Tavassol F, Lindhorst D, Stuehmer C, Bormann KH, Kampmann A, Mülhaupt R, Laschke MW, Menger MD, Gellrich NC, Rücker M (2009) Consequences of seeded cell type on vascularisation of tissue engineering constructs in vivo. Microvasc Res 78: 180-190.

Schumann P, Lindhorst D, von See C, Menzel N, Kampmann A, Tavassol F, Kokemüller H, Rana M, Gellrich NC, Rücker M (2014) Accelerating the early angiogenesis of tissue engineering constructs in vivo by the use of stem cells cultured in matrigel. J Biomed Mater Res A 102: 1652-1662.

Sclafani AP, Thomas JR, Cox AJ, Cooper MH (1997) Clinical and histologic response of subcutaneous expanded polytetrafluoroethylene (Gore-Tex) and porous highdensity polyethylene (Medpor) implants to acute and early infection. Arch Otolaryngol Head Neck Surg 123: 328-336.

Sefcik LS, Petrie Aronin CE, Wieghaus KA, Botchwey EA (2008) Sustained release of sphingosine 1-phosphate for therapeutic arteriogenesis and bone tissue engineering. Biomaterials 29: 2869-2877.

Shard AG, Tomlins PE (2006) Biocompatibility and the efficacy of medical implants. Regen Med 1: 789-800.

Sorg H, Krueger C, Vollmar B (2007) Intravital insights in skin wound healing using the mouse dorsal skin fold chamber. J Anat 211: 810-818.

Sorg H, Krueger C, Schulz T, Menger MD, Schmitz F, Vollmar B (2009) Effects of erythropoietin in skin wound healing are dose related. FASEB J 23: 3049-3058.

Steinstraesser L, Ring A, Bals R, Steinau HU, Langer S (2006) The human host defense peptide LL37/hCAP accelerates angiogenesis in PEGT/PBT biopolymers. Ann Plast Surg 56: 93-98.

Strieth S, Weger T, Bartesch C, Bittmann P, Stelter K, Berghaus A (2010) Biocompatibility of porous polyethylene implants tissue-engineered by extracellular matrix and VEGF. J Biomed Mater Res A 93: 1566-1573.

Tavassol F, Schumann P, Lindhorst D, Sinikovic B, Voss A, von See C, Kampmann A, Bormann KH, Carvalho C, Mülhaupt R, Harder Y, Laschke MW, Menger MD, Gellrich NC, Rücker M (2010) Accelerated angiogenic host tissue response to poly(L-lactide-co-glycolide) scaffolds by vitalization with osteoblast-like cells. Tissue Eng Part A 16: $2265-2279$.

Utzinger U, Baggett B, Weiss JA, Hoying JB, Edgar LT (2015) Large-scale time series microscopy of neovessel growth during angiogenesis. Angiogenesis 18: 219-232.

Vollmar B, Laschke MW, Rohan R, Koenig J, Menger MD (2001) In vivo imaging of physiological angiogenesis from immature to preovulatory ovarian follicles. Am J Pathol 159: 1661-1670.

Wettstein R, Mörsdorf P, Bächle A, Amon M, Pittet B, Menger MD, Harder Y (2007) Selective blockade of endothelin-B receptor improves survival of critically 
perfused musculocutaneous flaps. Langenbecks Arch Surg 392: $331-338$.

Wieghaus KA, Nickerson MM, Petrie Aronin CE, Sefcik LS, Price RJ, Paige MA, Brown ML, Botchwey EA (2008) Expansion of microvascular networks in vivo by phthalimide neovascular factor 1 (PNF1). Biomaterials 29: 4698-4708.

Wittig C, Laschke MW, Scheuer C, Menger MD (2013) Incorporation of bone marrow cells in pancreatic pseudoislets improves posttransplant vascularisation and endocrine function. PLoS One 8: e69975.

Yousefi S, Qin J, Dziennis S, Wang RK (2014) Assessment of microcirculation dynamics during cutaneous wound healing phases in vivo using optical microangiography. J Biomed Opt 19: 76015.

\section{Discussion with Reviewer}

Marietta Herrmann: The skinfold chamber has been widely applied to study neovascularisation of biomaterials and TE constructs. The dimensions of the constructs are however quite different from the target implant. Moreover, the testing is performed in a highly vascularised area. How do results translate when it comes to orthotopic implantation with the implantation site possibly being ischaemic?

Authors: The reviewer is correct that the size of biomaterial implants in the dorsal skinfold chamber is restricted to $\sim 3 \times 3 \times 1 \mathrm{~mm}$. In addition, the host tissue inside the chamber is well vascularised and, thus, provides optimal conditions for cell survival and vascular ingrowth, which are not always guaranteed at the orthotopic implantation site of clinically applied biomaterials. Nonetheless, the dorsal skinfold chamber model bears the major advantage that it provides highly standardised conditions for the in vivo characterisation of different biomaterials without biases due to individual size adjustments. Hence, results obtained in different studies can be directly compared with each other. Beyond, this model even allows the testing of biomaterials under clearly defined ischaemic conditions by pressing a silicone pad on the cutis of the back side of the chamber window.

Editor's note: The Scientific Editor responsible for this paper was Juerg Gasser. 